\title{
Dynamic Factor Analysis of the Distributed Innovation Process under the Internet Environment
}

\author{
Deyan Liu ${ }^{1, *}$ and Xiaoqin $\mathrm{Gao}^{2}$ \\ ${ }^{1}$ Wuhan Power Supply Company, Wuhan P.R.China \\ ${ }^{2}$ Wuhan University of Technology, Wuhan P.R.China \\ *Corresponding author
}

\begin{abstract}
The developments of information and communication technologies in combination with world-wide logistics processes can be seen as the main driver for distributed innovation processes. s. The key question is how multinational companies can manage such distributed innovation processes under the internet environment. This article introduces the concept of distributed innovation process. Then the author discusses the dynamic factor of distributed innovation process. At last, the author establishes the dynamic factor model of distributed innovation process.
\end{abstract}

Keywords-internet environment; dynamic factor; distributed innovation process

\section{INTRODUCTION}

With the rapid development of information technology in the world, more and more enterprises are under the internet environment. Internet/Intranet is fundamentally changing the shape of the existing economic structure and operation management system, which both in ways and means lead enterprises to the profound changes of technological innovation. The internet makes it easier to form the net of synergies multinational companies, Moreover, makes them conveniently access to important information. This has ensured the world-wide availability of both knowledge and information on the one side and - to a certain degree - the global availability of goods and materials on the other side. Multinational companies took advantage of these developments by creating distributed research and development (R\&D) facilities to shorten the innovation cycle, improve market understanding, and to reduce innovation cost. A famous example is given by IBM, which has outsourced programming activities already in the 1990s to India. Recently, IBM started to offer US employees to do their job in India with substantially reduced salary, which can be seen as a second wave, or even way, of outsourcing. The different collaborative enterprises can easily and effectively share resources in order to develop new and innovative products and services. Additionally this distributed innovation process reduces the innovation cycle.

Research on distributed innovation process is currently at its very beginning [2]. There are no studies available illustrating why and how multinational companies deal with distributed innovation processes. Consequently, the authors try to investigate a first set of dynamic factors that influence the evolution of distributed innovation processes. These factors help to understand why certain factors have a stronger and others have a weaker influence. In this article we present the results of an empirical study that was done by doing questionnaires and performing interviews with a representative number of Chinese companies, or more concretely with affiliates of multinational companies in China.

\section{DISTRIBUTED INNOVATION}

\section{A. Literature Review}

Distributed innovation is the successful implementation of creative ideas, tasks, or procedures by employees in different geographic locations. DI can be inter-firm or intra-firm cooperation, but narrows down the definition to be specifically cooperation that is possible as a direct result of globalization and the changing face of the world economy towards a knowledge based economy[3].

Distributed Innovation is an emerging frame work for a novel method of new product/service development, where knowledge from within and outside the organization is shared in an evolutionary dialogue, which consistently produces high quality results [4].

To exploit these opportunities faster, companies carry out their innovations by collaborating with outside partners, from whom they learn, transfer or in-source components of the new knowledge. This inter-organizational coordination has been referred to as distributed innovation [5] .

Distributed innovation offers exciting possibilities for a firm to capitalize on the creativity of its partners and customers, the management of distributed innovation requires firms to reexamine the mechanisms they use to govern innovation. A new model for managing distributed innovation, the community of creation is a governance mechanism for managing innovation that lies between the hierarchy-based (closed) mechanism and the market-based (open) mechanism for innovation management [6].

Distributed innovation is innovation across a particular intranet within an organizations supply chain or even virtual organizations. Distributed Innovation Management is defined as the process of managing innovation within and across groups of organizations joined to co-design and co-produce products and to over co-services to fulfill the customer's needs [7].

Globalization means Distributed Innovation, Distributed Innovation builds on clusters and the specialization of places as 
well as localized innovation and the capabilities that places develop as a result of high densities of Florida's “creative class.” [8].

There are five key action steps that companies and individuals must take to implement distributed innovation: Design processes to match the type of innovation required; Create structures to access and coordinate top global talent; Provide a share in the value created; Negotiate based on differing objectives, risk appetite, and power; $\mathrm{Be}$ open throughout the process [9].

The knowledge-based view puts forward a specific mechanism through which distributed $R \& D$ leads to greater innovation success: multiple locations enable the firm to access a larger number of different knowledge sources outside of the organization than it could in a single location [10].

Innovation is a distributed process that involves the collective efforts and the interaction of heterogeneous organisations. Each of those actors is specialised in specific activities, technologies and knowledge and innovation is the result of the combination and integration of their activities. Coordination is a key determinant for the viability of distributed innovation in that it stimulates complementarities across otherwise dispersed competences [11].

\section{B. Concept of Distributed Innovation}

Distributed innovation is innovation across a particular intranet within an organisation and even within key suppliers and strategic partners. This level of innovation is defined by all of the 'collaborative', 'project' and 'individual' innovation. A key feature of distributed innovation is that any individual within the intranet can search and 'surf' around the organisation looking at the innovation that to their own team or department. Senior manager can surf into particular individuals. The tools required for distributed innovation are in their infancy. A principal design feature will be that these tools must support 'structured collaboration', to allow any individual easily find the information they are looking for [12]. The contrast of two innovations shown in Table1.

TABLE I. CONTRAST OF TWO INNOVATION

\begin{tabular}{|l|c|c|}
\hline Contrast Project & $\begin{array}{l}\text { Distributed } \\
\text { innovation }\end{array}$ & $\begin{array}{l}\text { Traditional } \\
\text { collaborative } \\
\text { innovation }\end{array}$ \\
\hline $\begin{array}{l}\text { Coupling coefficient } \\
\text { of collaborative partners }\end{array}$ & Loose & Close \\
\hline $\begin{array}{l}\text { Autonomy degree } \\
\text { of collaborative partners }\end{array}$ & High & Low \\
\hline Heterogeneous degree & High & Low \\
\hline Distributed degree & High & Low \\
\hline Life cycle & Short & Long \\
\hline $\begin{array}{l}\text { Stability of } \\
\text { collaborative partners }\end{array}$ & Weak & Strong \\
\hline Scalability & Strong & Weaker \\
\hline Collaborative model & Dynamic & Static \\
\hline Connection model & $\begin{array}{l}\text { Internet } \\
\text { network }\end{array}$ & $\begin{array}{c}\text { Private } \\
\text { Network }\end{array}$ \\
\hline Management degree & complex & simple \\
\hline $\begin{array}{l}\text { Requirements of transaction } \\
\text { of Business process }\end{array}$ & Higher & Lower \\
\hline Degree of E-business & Higher & Lower \\
\hline Security requirements & Higher & Lower \\
\hline
\end{tabular}

\section{DISTRIBUTED INNOVATION PROCESS}

Distributed innovation process is essentially a process of knowledge transfer and absorption in distributed innovation networks, and acquires the creativity and knowledge from its partners and customers, obtains technical skills, and forms a high-efficiency community of creation [13]. It creates the new product/service development, where knowledge from within and outside the organization is shared in an evolutionary dialogue, which consistently produces high quality results [14].

Enterprises often face an innovation paradox; they must innovate in order to compete but in order to achieve the innovation, they may need to collaborate with Enterprises they compete against [15]. The reason for Enterprises engaging in distributed innovation process is primarily born out of necessity. Enterprises undertake distributed innovation process with suitable partner Enterprises to allow "shared risk, reduced costs and access to readily available skilled staff" [16] The benefits of collaborating can be viewed in terms of knowledge creation, dissemination, exploitation and learning [17]. Distributed innovation process can require differing levels of collaboration that are dependent upon the particular situation. Examples include licensing, contract research, and co-development [18]. While all three result in interaction between independent Enterprises for the purpose of innovation, the value of the knowledge flows for mutual learning between the Enterprises varies (see Fig. 1). Thus for the remainder of this paper, when we refer to distributed innovation process, we will be focusing on co-development activities as this requires the highest level of collaboration between Enterprises and highlights the challenges that must be addressed if distributed innovation process is to be successful.

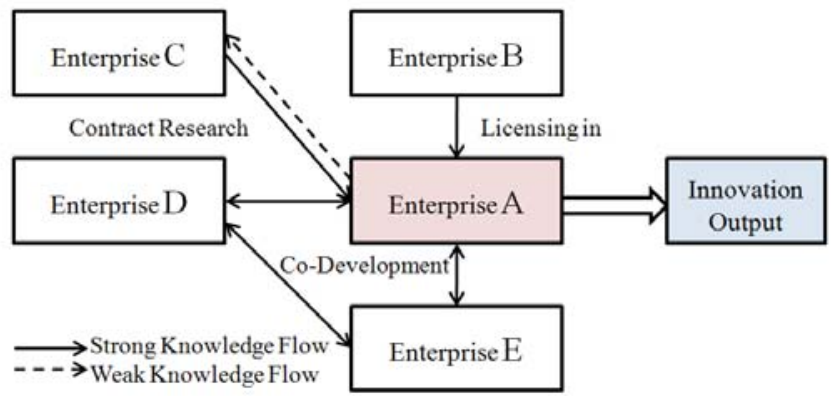

FIGURE I. DISTRIBUTED INNOVATION PROCESS

\section{DYNAMIC FACTOR OF DISTRIBUTED INNOVATION PROCESS}

\section{A. Location Factor}

"Location is everything" means that the physical location a firm chooses for its physical presence can make or break the future of the firm [19]. There are two distinct perspectives regarding the location of innovation activity. One general perspective emphasizes the benefits of distributed innovation, and derives primarily from the literatures on foreign direct investment and the knowledge-based view of the firm. The other general perspective emphasizes the costs of 
decentralization of innovation activity, and derives in part from the economics of transactions costs and agency[20].For adapting to the complex market environment, producing products which more accurately reflect local market characteristics, and getting special interests of location, location factor is the key of dynamic factor of distributed innovation. Therefore, we develop hypothesize that location factor includes customers localization needs, opening new domestic/foreign markets and distribution of sub-plant/company.

\section{B. Science and Technology Transfer Factor}

Science and technology transfer comes in two ways by technology transfer out of universities and institutes (public or semi-public) into commercial use and from overseas to domestic use. There are several ways to absorb alien technologies (spin-off, joint venture, alliance, licensing, purchase of technology, turnkey, etc.). For an infant industry, it is necessary to purchase new technology in order to catch up developed countries' technology capacity and achieve any possibility of 'leapfrog'. Thus the kind of approach to transfer and the extent to which content is transferred are important.

\section{Market Factor}

New products are offered to the market, and more sales revenues may then be achieved through commercialization processes, then fed back to the financial factor. In this study, the proposed boundary of this system includes a 'market factor' within it, but revealing just the external sources of demand for outputs, i.e. the structure of industry product markets. Similarly, here the 'government' does not touch upon the process of governmental decision-making; the government just supplies the needed financial support and tax incentives policies.

\section{Financial Factor}

This factor mainly includes private $R \& D$ budgets, venture capital, foreign depository receipts and government R\&D funding as sources of capital. The financial factor supports the essential 'labour cost' of the human resources factor while it invests in establishing and renewing essential equipment and new plant for the innovation commercialization factor. Besides, it also provides 'science capital and technology transfer' to the science and technology transfer factor. Government funding is scattered over the science and technology transfer factor and the innovation commercialization factor.

\section{E. Human Resources Factor}

Talented people are the key and crucial factor in the knowledge-based economy. A country possessing a comparative wealth of talent is likely to have a higher level of competitiveness. Human resources clearly contributed to the rapid development of Taiwan's IC industry. Our goal here will be to describe the Human resources factor providing 'embedded fruitful knowledge and R\&D capacity' to the innovation commercialization factor. It also provides the 'mental skill' to manage the staff of new organizations which spin off from the research institutes, joint ventures, alliances and turnkey plants.

\section{F. Innovation Commercialization Factor}

Before the product goes on sale in the market, it is essential to possess new innovation capability. New innovation capability includes embodied and disembodied technology know-how. The innovation process comprises process and product innovation. R\&D must generate new products and new processes to meet market requirements.

\section{DYNAMIC FACTOR MODEL OF DISTRIBUTED INNOVATION PROCESS}

Based on the above analysis, we have established the dynamic factor model of distributed innovation process, as shown in Figure 2. As can be seen from the chart, the dynamic factor model is composed of market factor, technology factor, profit factor, resources factor and environment factor. In the distributed innovation process, enterprises have a large number of exchanges and action relationship with these external environment, whereas, there are countless ties between these external environment and location. Because market, technology, resource and environment in different geographical space are different quality, the location factor is the core factor of dynamic factors of distributed innovation network, the effective integration of other factors around the location factor drives enterprise to distributed innovation.

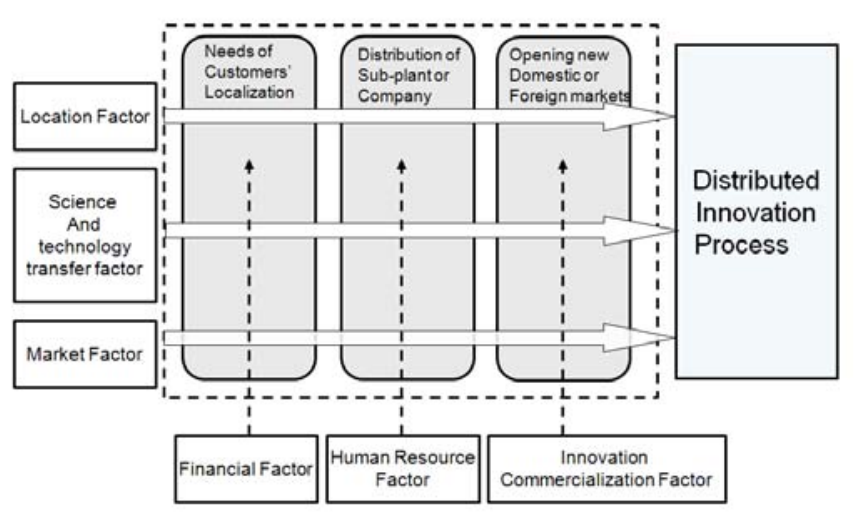

FIGURE II. DYNAMIC FACTOR MODEL OF DISTRIBUTED INNOVATION PROCESS

\section{CONCLUSIONS}

The main motive for an enterprise to carry out R\&D investments in different locations is to explore new markets and increase market share, because market scale and market potential are closely related to enterprise profits. For pursing maximum profit, a firm pays great attention to local market capacities. If the local market can offer great demand, a firm will increase its business investment, expand production, establish an R\&D institution to develop products in line with the local market, provide technical service and technical support, and provide timely information feedback. Setting up an $R \& D$ institution in the geographical location with big market potential and obvious market particularities, the firm can have a better understanding about the local market, then engage in targeted research and develop related products to support its products with advanced technology, to hold the monopoly position in the market and market share, to explore 
local market and even the world market. Especially the firms that have been entered the local market for a longer time and have a big amount of business must set up their own R\&D institutions urgently, to tie in with the local production; local customer needs and needs for further technology development. And also firms can make full use of local technology and resources, leverage its technological infrastructure to share the global $R \& D$ resources and reduce the $R \& D$ costs and innovation risks.

According to the dynamic factors model of enterprise distributed innovation the following conclusions can be summarized:

- Companies must deal with different dynamic factors driving distributed innovation processes.

- Companies must understand and manage their relationships.

- Companies need a game plan for conducting distributed innovation processes.

Furthermore, enterprises can consciously reform controlled factors to adapt to uncontrollable factors in order to enterprises distributed innovation continually.

In future research we plan to repeat our empirical investigation in Europe. This will identify both similarities and differences in managing distributed innovation. It is also planned to prove if the dynamic factor model can also be used in Europe.

\section{ACKNOWLEDGMENT}

This research was supported by a grant No. 71072076 from the National Natural Science Foundation of China.

\section{REFERENCES}

[1] McDougall P.: IBM Offers To Move Laid Off Workers To India, Information Week, Feb 2nd, 2009, http://www.informationweek.com/story/showArticle.jhtml?articleID=21 3000389, Accessed on Feb. 15th, 2009

[2] Gassmann, O.; Sutter, P.: Praxiswissen Innovationsmanagement. München, Carl Hanser Verlag 2008.

[3] Cummings, Jonathon N.“'Initiative for Distributed Innovation (IDI)." Http://www. Distributedinnovation.Org /index.php?p=overview.

[4] Alistair Bowden. Knowledge for free: distributed innovation as a source of learning, Public Policy and Administration, Vol. 20, No. 3, 2005:P5668.

[5] Coombs, R. and Metcalfe, S., Organizing for Innovation: Co-ordinating Distributed Innovation Capabilities. In Foss, N. J. and Mahnke, V. Competence, Governance, and Entrepreneurship. Oxford: Oxford University Press. 2001: P209-231.

[6] Mohanbir Sawhney, Emauela Prandelli. Communities of creation: management distributed innovation turbulent markets. California management review,;42,4;ABI/INFORM Global,2000:P24-49

[7] Jens Eschenbaecher, Falk Graser, and Axel Hahn,Governing Smart Business Networks by Means of Distributed Innovation Management. Smart Business Networks.Springer Berlin Heidelberg.2005: P307-319.

[8] Chris Kelly. Does Distributed Innovation fit with current innovation theory and policy? PUBP6803-Technology, Regions, and Policy .2006:P1-13.

[9] Ross Dawson. Living Networks: Leading Your Company, Customers, and Partners in the Hyper-Connected Economy. Financial Times Prentice Hall, 2002:P1-12.
[10] Aija Leiponen, Constance E. Helfat. When does distributed innovation activity make sense? Location, decentralization, and innovation success. Discussion papers: Cornell University.

[11] Davide Consoli, Pier Paolo Patrucco Sente Working paper University of Tampere Researc Unit for urban and regioanl development studies 2007:P2-4.

[12] David O’Sullivan, Lawrence Dooley, Jiangqiang Li, Tingting Zhu. Distributed innovation managemnet.2003:P8-9

[13] Mohanbir Sawhney, Emauela Prandelli, Communities of creation: management distributed innovation turbulent markets. California management review,42,4;ABI/INFORM Global, pp.24-49, 2000

[14] Alistair Bowden, Knowledge for free: distributed innovation as a source of learning, Public Policy and Administration, Vol. 20, pp.56-68, 2005

[15] Roberts, E (2002). Innovation: Driving Product, Process and Market Change. Jossey Bass Wiley

[16] Ryan, P, M Giblin and E Walshe (2004). From subcontracted R\&D to joint collaboration: the role of trust in facilitating this process. International Journal of Innovation and Technology Management, 1(2), 205-231.

[17] Rothwell, R (1992). Successful industrial innovation: critical success factors of the 1990's. R\&D Management, 22(3), 221-239.

[18] Haour, G (2004). Resolving the Innnovation Paradox: Enhancing Growth in Technology Companies. UK: Palgrave MacMillan.

[19] Chris Kelly, Does Distributed Innovation fit with current innovation theory and policy? Technology, Regions, and Policy. pp.1-13, 2006

[20] Aija Leiponen, Constance E. Helfat. When does distributed innovation activity make sense? Location, decentralization, and innovation success. Discussion papers: Cornell University. 